\title{
KAJIAN MENGENAI PROYEK RUANG KERJA KREATIF UNTUK MILENIAL
}

\author{
Chandra' $^{1)}$, J.M. Joko Priyono Santoso ${ }^{21}$
}

1) Program Studi S1 Arsitektur, Fakultas Teknik, Universitas Tarumanagara, chandra.tanamas96@gmail.com

2) Program Studi S1 Arsitektur, Fakultas Teknik, Universitas Tarumanagara, jokop@ft.untar.ac.id

\begin{abstract}
Abstrak
Industri kreatif di Indonesia sedang mendapatkan perhatian khusus oleh pemerintah karena dapat menciptakan sumber daya manusia yang mandiri dan produktif. Maka dari itu, industri kreatif mengalami perkembangan yang signifikan, tetapi persaingan antar freelancer akan semakin ketat, sedangkan generasi milenial yang baru memulai akan kesulitan untuk mengembangkan usahanya. Industri kreatif saat ini dipenuhi oleh generasi milenial yang memiliki karakteristik yang berbeda dengan generasi - generasi sebelumnya. Generasi milenial memiliki sifat leadership dan fleksibilitas yang tinggi sehingga ingin memegang dan tanggung jawab penuh terhadap proyek yang mereka kerjakan. Metode yang digunakan dalam perancangan adalah metode deskriptif kualitatif dan deskriptif komparatif dengan pattern language yang lebih diterapkan pada pembentukan program sehingga program yang dihasilkan sesuai dengan cara kerja dan perilaku generasi milenial, tetapi tidak mengesampingkan generasi - generasi sebelumnya. Daerah yang dipilih adalah Jakarta Barat, lebih tepatnya Kecamatan Kebon Jeruk, harapannya Kecamatan Kebon Jeruk yang ditujukan sebagai Service City memiliki ruang kerja untuk para komunitas industri kreatif dengan memberikan ruang pembelajaran dan ruang mengembangkan kreatifitas. Oleh sebab itu, Creative Hub merupakan sebuah sarana bagi generasi milenial sebagai freelancer yang bekerja pada sektor industri kreatif yang ingin menuangkan kreativitasnya dan memulai usaha. Dalam creative hub ini terdapat program yang dapat membantu freelancer dan dilengkapi dengan fasilitas penunjang seperti, kantor sewa, co - working, ruang pameran, dan workshop. Selain itu, creative hub ini juga mampu menjadi ruang rekreasi edukasi tentang industri kreatif dan pusat berkumpulnya pengrajin kreatif. Melalui Creative Hub ini, dapat menghasilkan lapangan kerja baru yang mandiri bagi generasi milenial sebagai freelancer, serta dapat memperoleh koneksi dan mengasah kemampuan.
\end{abstract}

Kata kunci: industri; kreatif; milenial; ruang Kerja

\begin{abstract}
The creative industry in Indonesia is getting special attention from the government because it can create independent and productive human resources. Therefore, the creative industry has experienced significant development, but the competition between freelancers will be increasingly stringent, while the millennial generation who are just starting out will find it difficult to expand their business. The creative industry is currently filled with millennials that have characteristics that are different from previous generations. Millennials have high leadership and flexibility so they want to hold and take full responsibility for the projects they work on. The method used in the design is qualitative and comparative descriptive with pattern language which is more applied to the formation of programs so that the programs produced are in accordance with the workings and behavior of the millennial generation, but do not override previous generations. The area chosen is West Jakarta, more precisely the District of Kebon Jeruk, hoping that the Kebon Jeruk Subdistrict which is intended as Service City has a work space for the creative industry community by providing learning space and space to develop creativity. Therefore, Creative Hub is a means for millennial generations as freelancers working in the creative industry sector who want to pour their creativity and start a business. In this creative hub there are programs that can help freelancers and are equipped with supporting facilities such as offices, co-working, exhibition rooms and workshops. In addition, this creative hub is also able to become an educational recreation room about the creative industry and the gathering center for creative craftsmen. Through this Creative Hub, it can generate new jobs that are independent for millennial generations as freelancers, and can gain connections and hone skills.
\end{abstract}

Keywords: creative; industry; millennials; working space 


\section{PENDAHULUAN}

Industri kreatif di Indonesia sedang mendapatkan perhatian khusus oleh pemerintah karena persaingan global dan lowongan pekerjaan yang tak sebanding dengan jumlah lulusan. Maka dari itu, pemerintah mencari alternatif perekonomian yang dapat menciptakan sumber daya manusia yang mandiri dan produktif, yaitu industri kreatif. Industri kreatif diharapkan menjadi salah satu sektor yang akan menjadi pondasi perekonomian Indonesia di masa yang akan datang.

Pada tahun 2016, kontribusi industri kreatif kepada perekonomian nasional sebesar 7,44\%. Kegiatan industri kreatif didukung oleh generasi milenial yang bekerja sebagai freelancer mengalami peningkatan sebesar 5,95\% pada tahun 2016. Dengan peningkatan ini, maka kinerja dan tempat kerja yang dibutuhkan untuk generasi milenial sebagai freelancer berubah. Selain itu, persaingan antar freelancer akan semakin ketat dari tahun ke tahun, sedangkan generasi milenial yang baru memulai akan kesulitan untuk mengembangkan usahanya karena keterbatasan modal, pengetahuan, dan network.

Generasi Milenial atau Generasi Y merupakan generasi dari sekelompok orang yang lahir pada tahun 1981 - 1994. Generasi milenial memiliki target hidup, yaitu work - lifestyle balance yang ingin memiliki waktu kerja yang fleksibel dan pekerjaan yang mereka lakukan tidak mengganggu gaya hidup mereka. Dengan target ini, generasi milenial memiliki sifat leadership yang tinggi dan ingin memiliki kekuasaan dan tanggung jawab penuh terhadap suatu proyek sehingga mereka dapat mengatur waktu kerja. Generasi milenial juga sedang memiliki usia produktivitas tertinggi saat ini, maka dari itu dunia terutama pangsa pasar memberikan perhatian lebih terhadap generasi milenial dengan cara memberikan support dan fasilitas yang dapat membantu dan menarik perhatian generasi milenial yang sesuai dengan kondisi dunia dan rutinitas mereka sehingga dapat meningkatkan produktivitas generasi tersebut.

Seorang freelancer menginginkan tempat kerja yang fleksibel sehingga generasi milenial tetap memiliki work - lifestyle balance. Tempat kerja yang fleksibel ini dapat dimana saja, tetapi jika dikelilingi oleh freelancer lain yang tidak sebidang pekerjaan akan ada kecenderungan membuat freelancer menjadi individualis, maka dari itu diperlukan suatu tempat yang spesifik pada pekerjaan tertentu sehingga freelancer dapat bertemu dengan freelancer lainnya yang sebidang dan dapat berkomunikasi, sharing pengalaman dan menambah networking.

Oleh karena itu, Creative Hub merupakan jawaban untuk masalah diatas. Creative Hub merupakan sebuah sarana bagi generasi milenial sebagai freelancer yang bekerja pada sektor industri kreatif yang ingin menuangkan kreativitasnya dan memulai usaha. Dalam creative hub ini terdapat program yang dapat membantu freelancer dan dilengkapi dengan fasilitas penunjang. Selain itu, creative hub ini juga mampu menjadi ruang rekreasi edukasi tentang industri kreatif dan pusat berkumpulnya pengrajin kreatif.

\section{KAJIAN LITERATUR}

\section{Jenis - Jenis Kantor Modern}

Maraknya dunia kewirausahaan digital di Indonesia pun mengindikasikan adanya kebutuhan bagi ruang kantor atau ruang bekerja alternatif. Karena karakter proses bekerjanya yang serba online, kantor tidak lagi harus berupa ruangan yang besar untuk menampung begitu banyak karyawan. Tidak sedikit pengusaha yang memulai bisnisnya dengan tim kecil ataupun bekerja dengan anggota tim di tempat berlainan karena adanya akses internet. Dunia bisnis semakin menyadari adanya kebutuhan berbeda bagi industri berbeda sehingga ruang kerja pun berbeda-beda bentuknya. Menurut Forum Teropong, sekarang ini ruang kerja tidak lagi terlihat begitu-begitu saja, ada berbagai macam jenis ruang kantor yang mulai populer.

\section{a. Virtual Office}

Sebuah virtual office tidak benar-benar ada secara fisik. Yang ditawarkan adalah alamat surat dan poin kontak yang bisa dihubungi. Startup tersebut seakan beralamat di gedung 
perkantoran di mana virtual office berada. Startup dijalankan di rumah, bisnis tersebut akan tetap mendapatkan kredibilitas di antara pengguna potensialnya. Selain itu, dengan mengalamatkan urusan bisnis kepada virtual office, pengusaha yang bekerja dari rumah akan terjaga privasinya karena urusan bisnis tidak dialamatkan ke rumah pribadi.

Beberapa keuntungan komunikasi yang ditawarkan virtual office adalah resepsionis, asisten, call center, dan lainnya. Selain itu, ada juga space service, yang melibatkan alamat prestisius yang biasa ditawarkan sebuah virtual office. Servis ini memberikan alamat profesional, alamat surat, tempat meeting, dan kesempatan menyewa tempat untuk sementara waktu.

b. Serviced Office

Tempat kerja yang satu ini bukan hanya menyediakan tempat tetapi juga segala pengurusnya. Sebuah manajemen fasilitas yang menjadi pengurusnya akan menyewakan ruangan kerja atau lantai kerja untuk beberapa perusahaan berbeda. Biasanya serviced office juga terletak di pusat bisnis di kota-kota besar. Tujuan dibentuknya ruang kantor serviced office adalah untuk memberikan fleksibilitas bagi pengusaha yang menggunakannya karena biasanya dapat disewa dengan mudah.

Serviced office ditujukan untuk perusahaan yang baru memasuki sebuah lokasi baru, startup, atau pekerjaan project-based. Serviced office dapat membantu menghemat biaya human resource karena pengusaha tidak harus memiliki staf - nya sendiri apalagi bagi pengusaha startup.

c. Co - Working Space

Coworking space adalah tempat di mana pengusaha dari bisnis yang berbeda dapat berbagi kantor. Co - working space memiliki organisasi yang mengorganisir aktivitas di dalamnya. Co working space seringkali dimulai dari sebuah komunitas yang memiliki visi yang sama sehingga memilih untuk bekerja dalam ruang kerja yang sama.

Ruang kerja seperti ini cocok untuk startup yang memiliki tim kurang dari enam orang, sehingga tidak sulit berbagi ruangan dengan tim lainnya. Selain itu, entrepreneur yang sedang traveling juga bisa menggunakan co - working space yang dapat disewa per hari. Selain menjadi tempat bekerja yang kondusif, co - working space juga sering mengadakan event komunitas dan pengusaha sehingga entrepreneur yang bekerja di dalamnya tidak hanya bekerja tetapi juga memperluas network.

\section{Creative Hub}

Creative hub dapat mengembangkan usaha kecil kreatif dengan menggabungkan dan mempertemukan freelancer dan pemilik startup atau orang - orang kreatif yang memiliki bakat, kemampuan, dan bidang pekerjaan yang bervariasi di suatu tempat dimana tempat tersebut sudah disediakan sumber daya, seperti tempat mencari inspirasi dan peralatan yang mendukung, serta orang yang ahli mengoperasikannya untuk membantu mengembangkan projek dan usaha mereka. Creative hub dapat menjadi wadah bagi manusia pekerja generasi milenial untuk memulai usaha dan dapat mengembangkan bakat dan kemampuan, serta memperluas koneksi.

Munculnya creative hub terjadi karena adanya ketidakpastian dalam sosial dan ekonomi, serta adanya keterbatasan seseorang untuk menunjukkan kreatifitas dan inovasi mereka. Creative Hub dapat memberikan dampak positif bagi komunitas dan masyarakat terutama kepada generasi milenial, seperti membuat produk baru, mengembangkan bakat, pelatihan, research and development, memperluas koneksi. Creative hub dapat membentuk koneksi yang akan mengembangkan industri kreatif pada suatu kota dalam skala lokal, regional, maupun internasional, serta dapat membuka lapangan pekerjaan yang lebih beredukasi dan lebih memberikan peluang. Menurut Creative HubKit, creative hub adalah tempat, baik fisik maupun virtual, yang menyatukan orang-orang kreatif dan berperan sebagai penghubung yang menyediakan ruang dan dukungan untuk menjalin koneksi, pengembangan bisnis dan keterlibatan masyarakat dalam sektor kreatif, budaya dan teknologi. 
Pusat kreatif memiliki berbagai tujuan:

a Untuk memberikan dukungan melalui layanan dan atau fasilitas untuk gagasan, proyek, organisasi, dan bisnis yang menjadi tuan rumah, baik dalam jangka panjang maupun jangka pendek, termasuk acara, pelatihan keterampilan, pengembangan kapasitas, dan peluang global.

b Untuk memfasilitasi kolaborasi dan jaringan di antara komunitasnya.

c Untuk menjangkau pusat penelitian dan pengembangan, lembaga, industri kreatif dan non-kreatif.

d Untuk berkomunikasi dan terlibat dengan khalayak yang lebih luas, mengembangkan strategi komunikasi aktif.

e Untuk memperjuangkan dan merayakan bakat yang muncul; menjelajahi batas-batas praktik kontemporer dan mengambil risiko terhadap inovasi.

The Creative Toolkit dari British Council membagi creative hub menjadi 6 varian, yaitu studio, centre, network, cluster, online platform, alternative. Kementerian Pariwisata dan Ekonomi Kreatif (Kemenparekraf) menyiapkan empat tahap untuk membentuk pusat kreatif yakni melalui tahap ekspresi, diseminasi, inovasi, dan inkubasi. Empat tahap inilah yang akan membentuk pusat kreatif di Indonesia, adapun yang dimaksud dengan keempat tahap tersebut antara lain adalah ekspresi, diseminasi, inovasi, inkubasi

\section{Perilaku Generasi Milenial}

Generasi Milenial atau Generasi Y merupakan generasi dari sekelompok orang yang lahir pada tahun 1981 - 1994 setelah Generasi X yang lahir pada tahun 1965 - 1980. Generasi Milenial tumbuh dalam dunia yang sudah dipenuhi oleh elektronik, internet, dan sociallynetworked. Millennials memiliki karakteristik yang terbagi menjadi 3 aspek, yaitu creative, connected, dan confidence. Creative, milenials adalah orang yang biasa berpikir out of the box, kaya akan ide dan gagasan dan mampu mengkomunikasikan ide dan gagasan itu dengan baik. Generasi millennial termasuk generasi kreatif, salah satu bukti yang menunjukkan adalah tumbuhnya industri start up dan industri kreatif lain yang di motori oleh anak muda. Connected, milenials adalah pribadi - pribadi yang pandai bersosialisasi terutama dalam komunitas yang mereka ikuti, mereka juga aktif di sosial media dan internet. Sosial media dan internet sudah menjadi kebutuhan. Confidence, milenials adalah orang yang sangat percaya diri, berani mengemukakan pendapat dan berani berdebat di depan publik. Karakter tersebut terkonfirmasi jika kita melihat generasi millennials berani berdebat melalui media sosial. Generasi milenial juga memiliki pikiran - pikiran yang lebih open-minded ketimbang generasi sebelumnya. Hal ini disebabkan oleh elektronik, internet, dan social media yang membantu proses globalisasi lebih cepat.

Kaum generasi milenial dapat mempengaruhi budaya, nilai - nilai sosial, pelaku, dan pola pikir suatu daerah. Masyarakat yang dulunya bersifat komunal menjadi masyarakat yang individualis, masyarakat yang dulunya sederhana menjadi masyarakat konsumtif, masyarakat yang dulunya berpola pikir konservatif menjadi masyarakat yang lebih terbuka dan modern. Selain itu, dapat juga membuat masyarakat dengan vicious cycle (melakukan pekerjaan yang sama setiap generasi bahkan dapat membuat lebih buruk) menjadi virtuous cycle (membuat generasi - generasi memiliki kehidupan yang lebih baik).

Pada era globalisasi ini, generasi milenial juga memiliki lifestyle yang berubah - ubah sesuai dengan trend yang ada sehingga generasi milenial merupakan generasi yang memiliki daya beli maka dari itu dapat mempengaruhi dan merubah paradigma dan konsep arah marketing. Kebutuhan generasi milenial juga berbeda dengan generasi - generasi sebelumnya dimana mereka memiliki trend dimana ada keharusan untuk membawa mobile devices, seperti laptop dan smartphone sehingga mereka menjadi kecanduan. 


\section{METODE}

Metode perancangan yang digunakan melalui data sekunder yang didapatkan dari media perantara secara tidak langsung berupa buku yang dipublikasikan dan yang tidak dipublikasikan. Metode desain yang digunakan untuk program adalah metode interaksi dengan pattern language yang diaplikasikan dalam matrix yang menjelaskan perubahan - perubahan sikap dan perilaku manusia dari waktu ke waktu. Variabel yang digunakan merupakan perbedaan - perbedaan dari 3 generasi, yaitu generasi baby boomers, generasi $x$, dan generasi milenial. Aspek tersebut ditentukan berdasarkan aspek apa saja yang dibutuhkan creative hub yang diusulkan sehingga menciptakan program yang dapat menampung atau mewadahi karakteristik, kinerja, kemampuan dan teknologi yang digunakan oleh generasi milenial. Dengan melihat aspek ini, akan terlihat adanya perbedaan disetiap generasi, adanya perkembangan dari generasi satu ke generasi lainnya melalui proses menjadi lebih baik dan ada yang berbeda disetiap generasi sehingga memunculkan suatu kesimpulan apa yang membuat adanya perbedaan itu.

\section{DISKUSI DAN HASIL}

Matrix Program

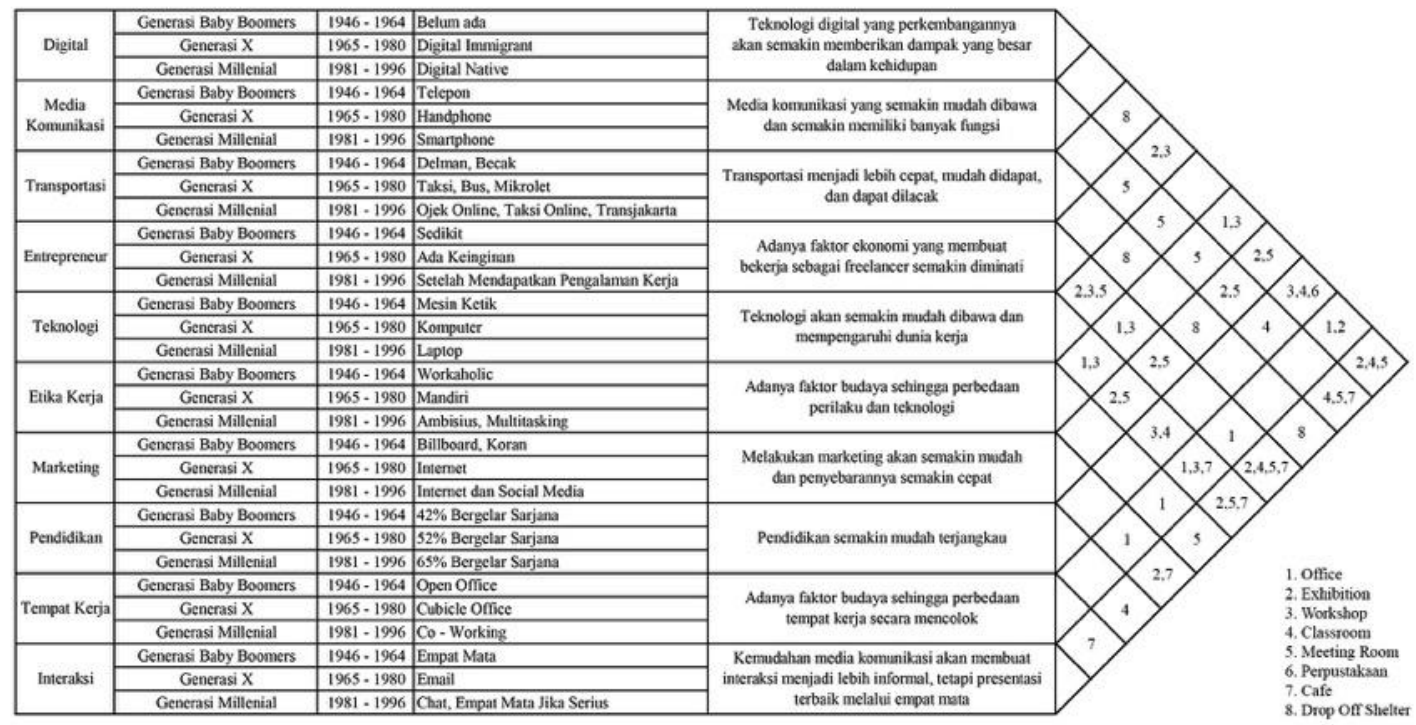

Gambar 1. Matrix Program

Sumber: Penulis, 2019

Variabel pertama adalah digital. Pada generasi baby boomers, mereka belum kenal atau ahli dalam menggunakan teknologi digital. Pada generasi $x$, mereka merupakan generasi transisi era digital dimana mereka masih menyesuaikan penggunaan teknologi digital dan pada generasi ini teknologi digital masih dalam tahap perkebangan sehingga penggunaannya masih belum umum, mereka disebut sebagai digital immigrant. Pada generasi milenial, mereka sudah bisa merasakan teknologi digital yang dapat dikatakan sudah digunakan secara global dan generasi ini telah menyentuh teknologi digital saat mereka dalam usia pembelajaran dan mereka menjadi lebih lihai dalam menggunakan teknologi digital sehingga mereka dikatakan sebagai digital native. Dalam penjabaran pada setiap generasi, maka dapat disimpulkan bahwa teknologi digital akan terus berkembang dan semakin mudah dijangkau, serta penggunaannya akan yang akan memiliki efek yang besar terhadap kehidupan.

Variabel kedua adalah media komunikasi. Pada generasi baby boomers, mereka masih berkomunikasi jarak jauh menggunakan telepon kabel yang penggunaannya hanya pada tempat tertentu dan kurang fleksibel. Pada generasi $x$, mereka beromunikasi menggunakan handphone yang sudah lebih praktis dan dapat dibawa kemana saja. Pada generasi milenial, media komunikasi sudah semakin canggih dengan menggunakan smartphone yang tidak hanya 
dapat melakukan panggilan atau pesan singkat saja, tetapi sudah dilengkapi dengan media media hiburan yang semakin beragam dan dapat dipilih sendiri sehingga waktu pemakaiannya semakin lama dan dapat memberikan dampak positif dan negatif ke penggunanya. Dalam penjabaran pada setiap generasi, dapat disimpulkan bahwa media komunikasi semakin mudah dibawa dan semakin memiliki banyak fungsi yang tidak hanya sebagai alat komunikasi, tetapi dapat menjadi media hiburan yang dapat menggantikan media atau teknologi lainnya.

Variabel ketiga adalah transportasi umum. Pada generasi baby boomers, mereka pergi bekerja biasa menggunakan delman dan becak yang masih menggunakan energi dari makhluk hidup sehingga memiliki limit dari segi kecepatan dan tenaga yang dipakai, serta jarak tempuh yang tidak bisa terlalu jauh. Pada generasi $x$, mereka sudah dapat menggunakan taksi, bus, dan mikrolet di Indonesia yang sudah menggunakan tenaga mesin sehingga jarak tempuh sudah dapat semakin jauh, tetapi kurangnya ketertibban dalam mengangkut penumpang. Pada generasi milenial, mereka dapat menggunakan smartphone untuk memesan ojek dan taksi secara online sehingga sudah semakin praktis dan tidak perlu menunggu pada tempat tertentu, seperti halte. Juga terdapat transjakarta yang memiliki akses khusus tanpa harus terkena macet sehingga jarak tempuh semakin singkat. Dalam penjabaran pada setiap generasi, dapat disimpulkan bahwa transportasi umum sudah semakin baik, mudah didapat, dan cepat, serta dapat dilacak menggunakan smartphone.

Varibel keempat adalah entrepreneur. Pada generasi baby boomers, yang bekerja dan memiliki minat sebagai entrepreneur sedikit karena mereka lebih memilih untuk kerja pada lingkungan perkantoran. Pada generasi $x$, sudah mulai ada perkembangan dan memiliki keinginan menjadi entrepreneur karena adanya tuntutan ekonomi dan kesempatan kerja. Pada generasi milenial, mereka melihat bahwa menjadi entrepreneur membuat mereka menjadi lebih fleksibel dalam membagi waktu kerja dengan gaya hidup, tetapi untuk menjadi entrepreneur juga memerlukan pengalaman dalam bidang yang dikerjakan. Dalam penjabaran pada setiap generasi, dapat disimpulkan bahwa menjadi entrepreneur akan semakin diminati karena adanya tuntutan ekonomi, gaya hidup, dan minimnya kesempatan kerja.

Variabel kelima adalah teknologi. Pada generasi baby boomers, teknologi yang mereka gunakan sebagai alat kerja mereka adalah mesin ketik yang penggunaannya kurang praktis dan dibutuhkan ketelitian sehingga tidak melakukan kesalahan dalam mengetik, serta waktu pengetikan relatif lama. Pada generasi $x$, teknologi yang mereka gunakan adalah komputer yang sudah memiliki media penyimpanan secara digital, serta tidak hanya untuk bekerja, tetapi sudah dapat digunakan sebagai media hiburan dan edukasi. Pada generasi milenial, teknologi yang digunakan adalah laptop yang lebih praktis dan dapat dibawa kemana - mana yang memiliki kemampuan yang sama seperti komputer, serta mereka dapat bekerja lebih fleksibel. Dalam penjabaran pada setiap generasi, dapat disimpulkan bahwa teknologi yang digunakan untuk bekerja akan semakin mudah dibawa dan mempengaruhi cara mereka bekerja.

Variabel keenam adalah etika bekerja. Pada generasi baby boomers, mereka selalu bekerja terus - menerus demi memajukan perusahaan dan sangat sedikit memiliki waktu dengan keluarga sehingga generasi ini disebut workaholic. Pada generasi $x$, dari dampak etika kerja yang dilakukan generasi baby boomers, generasi $x$ menjadi lebih mandiri karena dalam proses mereka tumbuh lebih sedikit mendapatkan pembelajaran dari orang tuanya. Pada generasi milenial, dengan teknologi yang sudah canggih, mereka dapat melakukan multitasking dalam melakukan pekerjaan dan lebih ambisius karena mereka ingin melakukan hal yang lebih seperti menjadi entrepreneur demi menstabilkan perekonomian mereka. Dalam penjabaran pada setiap generasi, dapat disimpulkan bahwa adanya faktor budaya, ekonomi, dan teknologi sehingga mereka memiliki etika dalam bekerja yang berbeda - beda.

Variabel ketujuh adalah marketing. Pada generasi baby boomers, cara marketing lebih menggunakan billboard dan koran karena cara tersebut lebih mudah menjangkau mereka. Pada generasi $x$, cara marketing lebih dilakukan di internet karena akan lebih mudah menjangkau mereka melalui internet dengan penggunaan internet pada tempat kerja maupun di rumah, selain itu, mereka dapat mencari dan memperoleh informasi tentang yang di - 
marketing - kan secara langsung melalui internet. Pada generasi milenial, selain melalui internet, cara marketing juga melalui media social pada smartphone karena penggunaan smartphone penggunaannya tinggi. Dalam penjabaran pada setiap generasi, dapat disimpulkan bahwa cara marketing akan selalu menemukan cara bagaimana iklan mereka dapat sering dilihat dan penyebarannya akan semakin cepat.

Variabel kedelapan adalah Pendidikan. Pada generasi baby boomers, pendidikan sulit diakses terutama kepada masyarakat miskin sehingga gelar sarjana hanya orang dari kalangan tertentu yang memilikinya. Pada generasi $x$, pendidikan mulai dapat diakses dan adanya peningkatan orang yang memiliki gelar sarjana. Pada generasi milenial, pendidikan sudah mulai dapat dijangkau ke semua kalangan dengan bantuan pemerintah sehingga yang memiliki gelar sarjana lebih banyak lagi. Dalam penjabaran pada setiap generasi, dapat disimpulkan bahwa pendidikan kedepannya akan lebih mudah dijangkau dan bantuan dari pemerintah demi perekonomian negara akan semakin besar.

Variabel kesembilan adalah tempat kerja. Pada generasi baby boomers, mereka lebih menerapkan open office karena kurang canggihnya teknologi pada saat itu dan diperlukan komunikasi dan interaksi. Pada generasi $x$, mereka menerapkan cubicle office karena sifat mereka yang mandiri dan pekerja dapat lebih focus ke pekerjaan mereka. Pada generasi milenial, muncul ruang kerja baru yang dapat mewadahi mereka sebagai freelancer, yaitu co working dengan fleksibilitas yang tinggi dan tidak terikat dengan jam kerja. Dalam penjabaran pada setiap generasi, dapat disimpulkan bahwa adanya perbedaan budaya antar generasi sehingga timbul ruang kerja yang menyesuaikan dengan cara kerja mereka.

Variabel kesepuluh adalah interaksi dalam bekerja. Pada generasi baby boomers, mereka lebih suka melakukan empat mata karena mereka dapat lebih memahami lawan bicara mereka. Pada generasi $x$, sudah ada internet maka mereka akan lebih memilih menggunakan email dan lebih praktis dapat berkomunikasi jarak jauh dan menggirim file ke pengguna tertentu. Pada generasi milenial, dengan perkembangan teknologi yang lebih maju, mereka menggunakan chat pada smartphone mereka sehingga mereka dapat berkomunikasi dimana saja, tetapi mereka juga akan melakukan empat mata jika pembicaraan yang mereka lakukan serius. Dalam penjabaran pada setiap generasi, dapat disimpulkan bahwa kemudahan media komunikasi dapat membuat interaksi menjadi lebih informal, tetapi kehadiran diri tetap menjadi pilihan utama pada aspek tertentu.

Setelah penjabaran setiap variabel, setiap variabel koneksikan dengan variabel lainnya sehingga membentuk sebuah program. Dapat dikatakan pada program tersebut terdapat aspek tertentu yang harus dimiliki dalam program tersebut, seperti aktivitas, fasilitas, dan target pelaku. Program office terbentuk dari hasil antara variabel digital, entrepreneur, teknologi, etika kerja, marketing, dan tempat kerja. Program ruang pameran terbentuk dari hasil antara variabel digital, marketing, entrepreneur, etika kerja, teknologi, dan interaksi. Program workshop terbentuk dari hasil antara variabel digital, entrepreneur, teknologi, pendidikan, dan tempat kerja. Program kelas terbentuk dari hasil antara variabel pendidikan, entrepreneur, interaksi, teknologi, digital, dan media komunikasi. Program meeting room terbentuk dari hasil antara variabel digital, media komunikasi, marketing, entrepreneur, teknologi, dan interaksi. Pada program ruang baca dan material sample terbentuk dari hasil antara variabel digital dan pendidikan. Pada program café terbentuk dari hasil antara variabel tempat kerja, interaksi, entrepreneur, teknologi, marketing, dan media komunikasi. Drop off shelter terbentuk dari hasil antara variabel transportasi, teknologi, marketing, dan interaksi.

Projek yang diusulkan berada di DKI Jakarta, lebih tepatnya pada Jakarta Barat. Jakarta merupakan Kota Metropolitan dengan beragam peran dan fungsi yang disandangnya. Hampir semua markas utama perusahaan besar nasional maupun multi - nasional berlokasi di Jakarta. Jakarta telah memposisikan dirinya sebagai pusat perdagangan dan jasa. Jakarta mempunyai potensi yang sangat tinggi. 
Table 1. Scoring Tapak

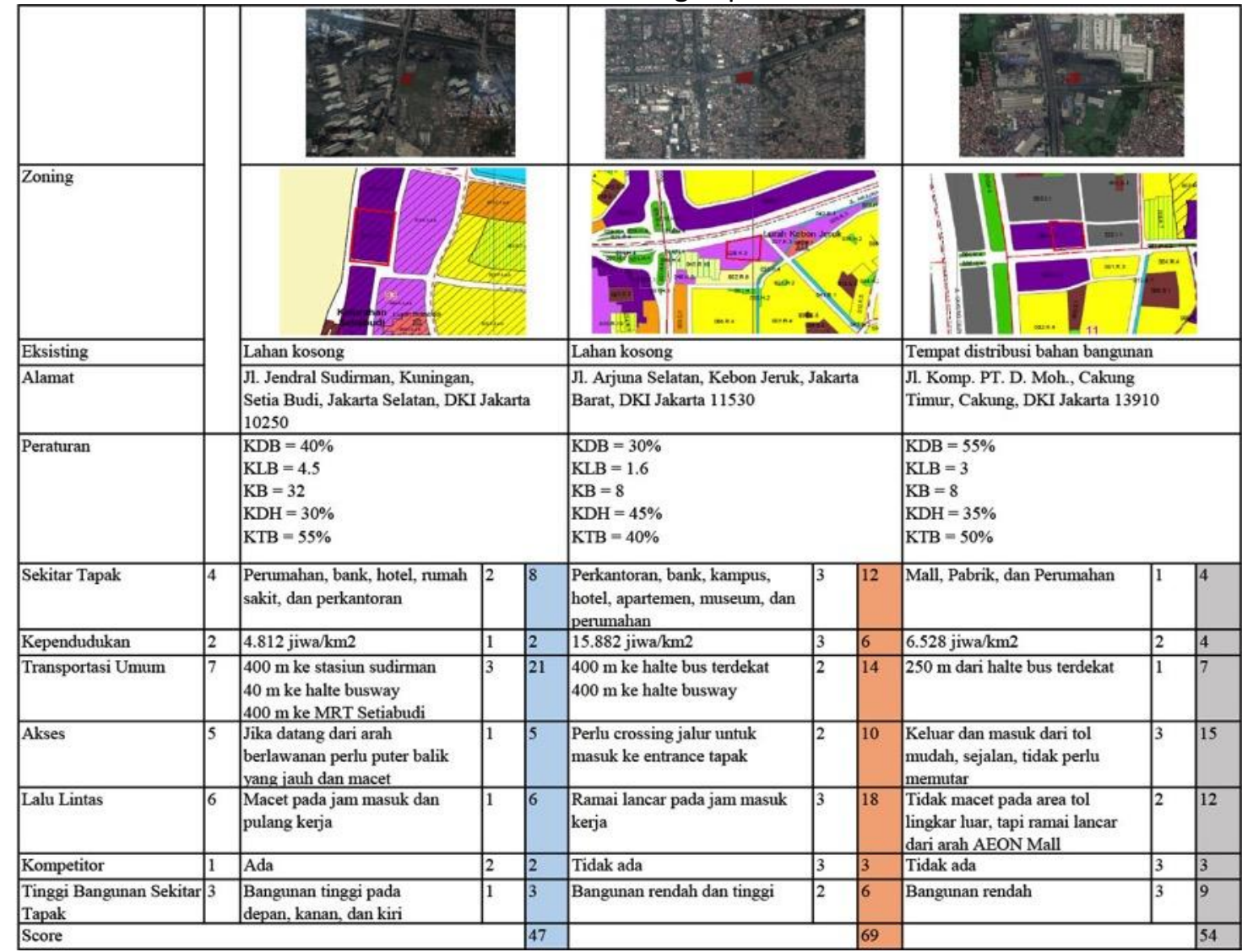

Sumber: Penulis, 2019

Dalam mencari tapak yang sesuai dengan fungsi yang diusulkan, maka dilakukan perbandingan antar tapak yang dikandidatkan menggunakan sistem scoring. Pemberian nilai pada aspek disisi kiri dalam skala 1 sampai 7 dimana 7 merupakan nilai teringgi dimana aspek tersebut sangat dibutuhkan dalam proyek creative hub. Transportasi umum merupakan aspek tertinggi dimana lebih ditargetkan untuk mengurangi penggunaan kendaraan pribadi sehingga tidak menambahkan kemacetan disekitar tapak. Aspek tertinggi kedua adalah lalu lintas dimana dipertimbangkan durasi dan kapan terjadi kemacetan sehingga adanya proyek creative hub tidak menambah kemacetan. Nilai yang berada pada setiap tapak diberikan skala 1 sampai 3 dimana diberikan nilai 3 jika memiliki aspek terbaik dibanding tapak lainnya. Lalu nilai indikator dan nilai tapak dikalikan menghasilkan score dan ditotal sehingga tapak yang memiliki total score tertinggi dijadikan tapak proyek.

Tapak di Kebon Jeruk memiliki hasil scoring tertinggi dengan memiliki keunggulan dalam kependudukan, lalu lintas, dan kompetitor dibandingkan dengan tapak terpilih yang lain. Kecamatan Kebon Jeruk memiliki luas 13,88 persen terhadap wilayah Kota Adm. Jakarta Barat, mempunyai peranan dan fungsi strategis bagi pengembangan kegiatan ekonomi, sosial, budaya dan lingkungan kota. Sejalan dengan kebijakan Pemda Kota Administrasi Jakarta Barat sebagai Service City, kebijakan sektor industri pengolahan lebih berorientasi kepada pengembangan industri pilihan (selected industry), yaitu industri berteknologi tinggi dan non polusi dengan memperhatikan aspek padat karya, hemat ruang dan air. Diantara industri pilihan tersebut, terdapat industri pilihan yang menghasilkan komoditi unggulan berdasarkan nilai tambah dan penyerapan tenaga kerja. 


\section{ZONASI}

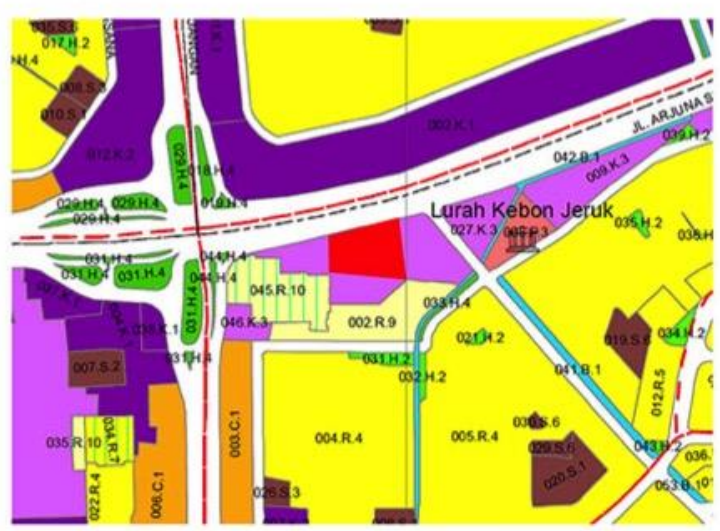

Gambar 2. Zonasi

Sumber: Buku RDTR dan TPZ DKI Lampiran III

Dengan zonasi yang ditetapkan pemda, maka kawasan Kebon Jeruk mengalami pengembangan menjadi adanya pengembangan pusat perkantoran, perdagangan, dan jasa; terpeliharanya fungsi permukiman dan pengembangan kawasan permukiman baru; pengembangan pusat perkantoran dan jasa dilengkapi prasarana yang terintegrasi dengan angkutan umum massal; pengembangan kawasan perdagangan dengan konsep KDB rendah.

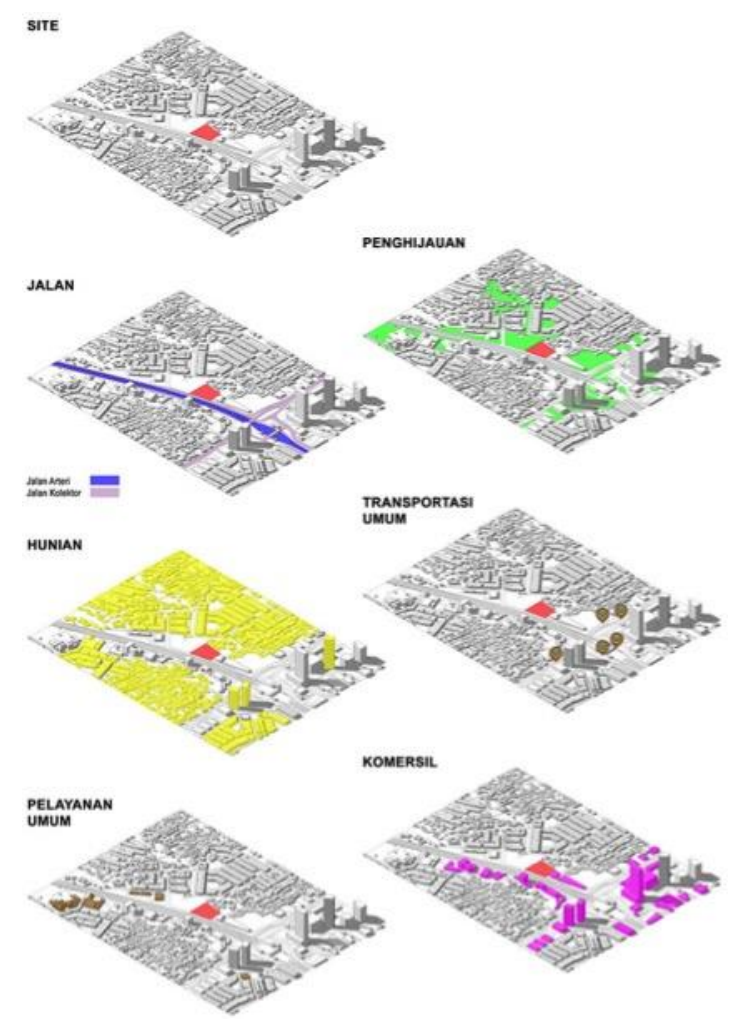

Gambar 3. Data Mikro

Sumber: Penulis, 2019 


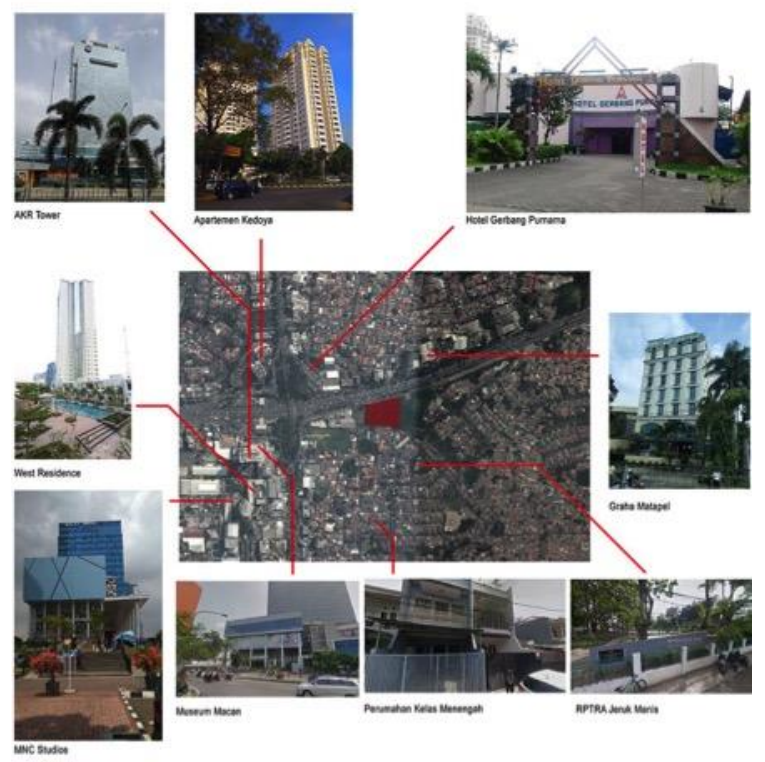

Gambar 4. Bangunan Sekitar Tapak Sumber: Penulis, 2019
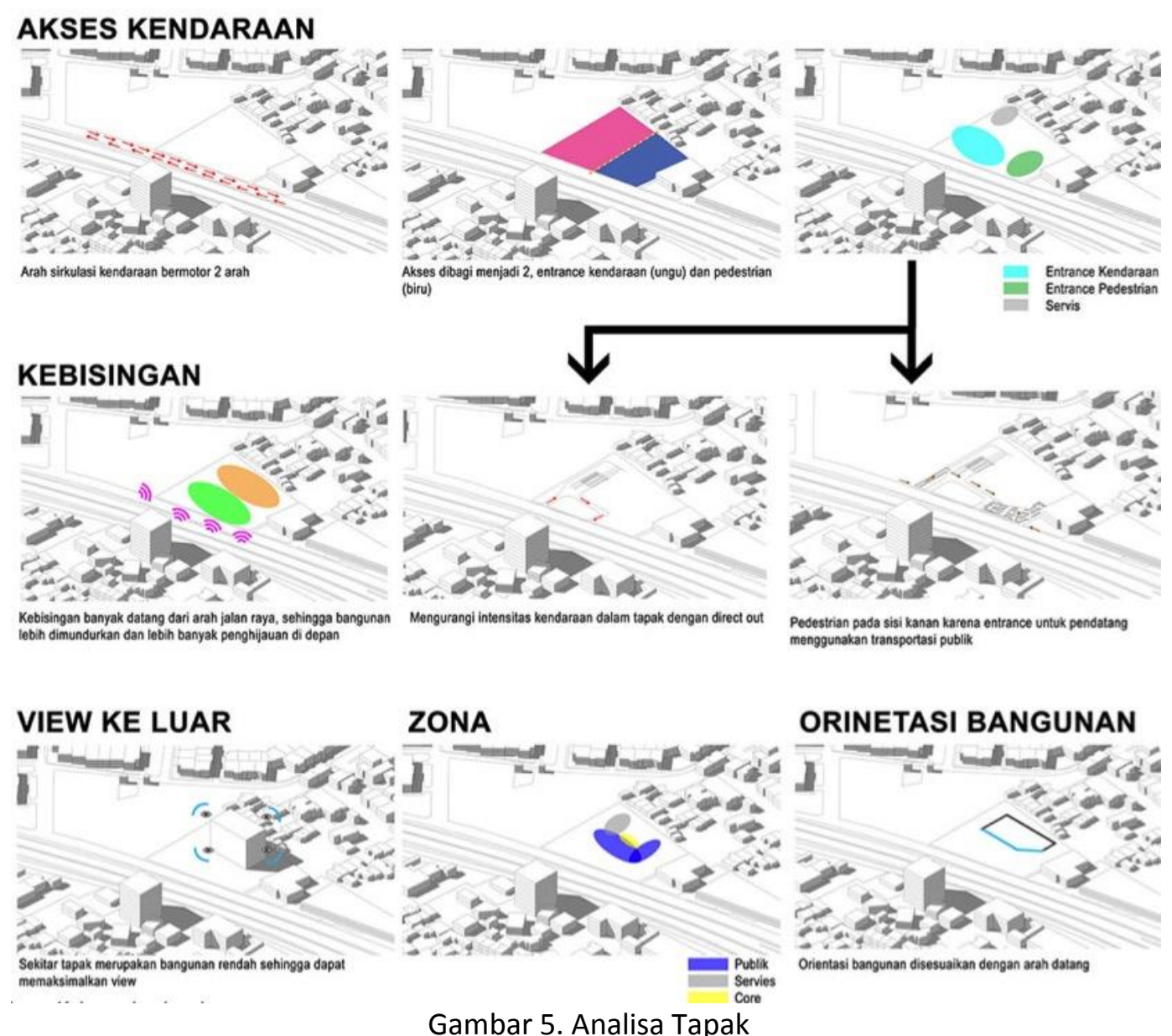
Sumber: Penulis, 2019 


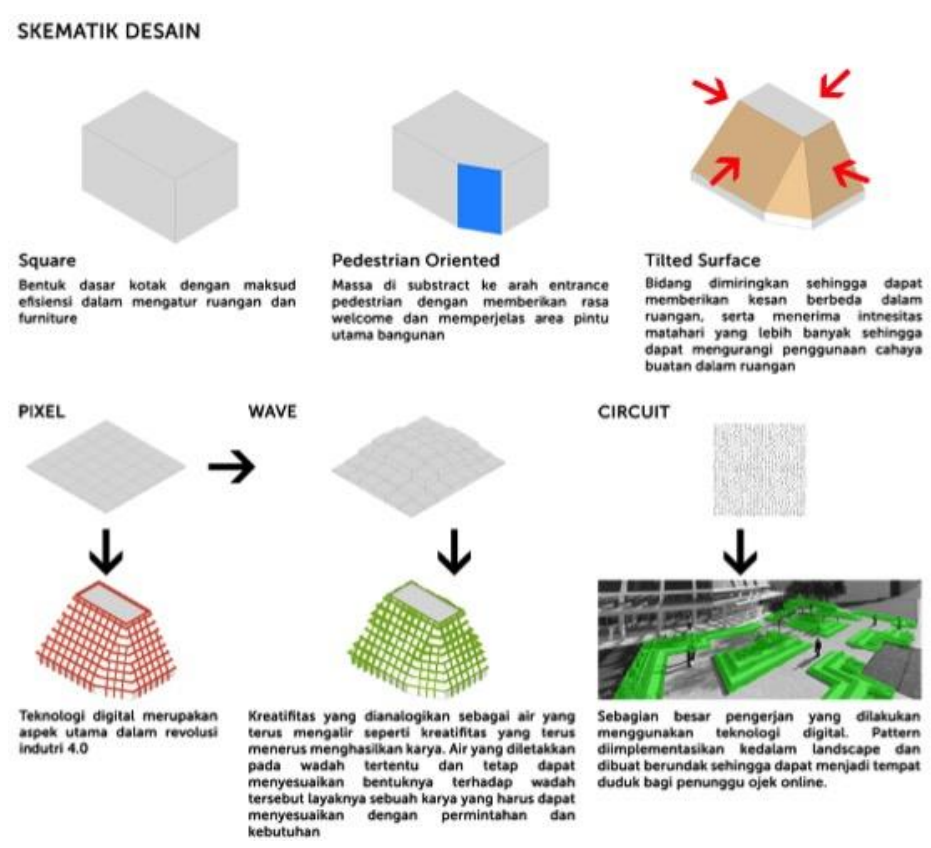

Gambar 6. Skematik Desain

Sumber: Penulis, 2019

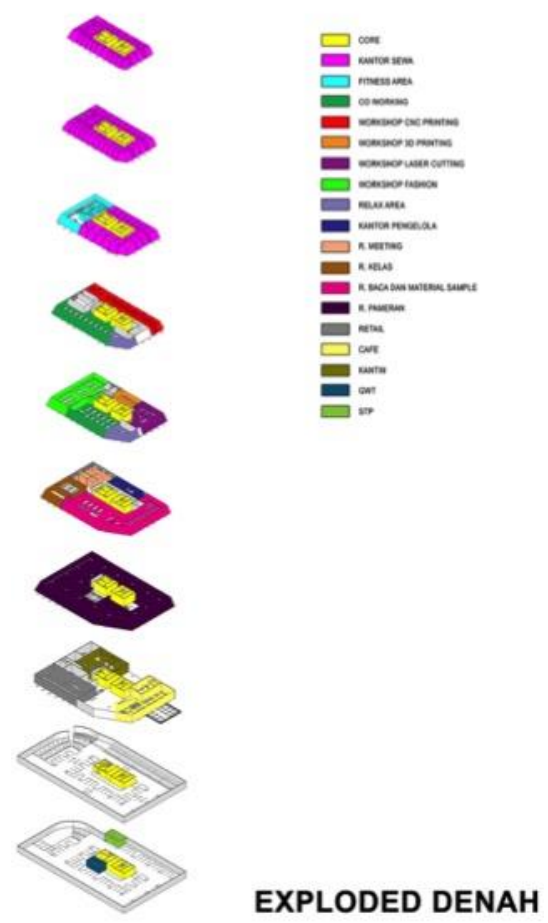

Gambar 7. Exploded Denah

Sumber: Penulis, 2019 


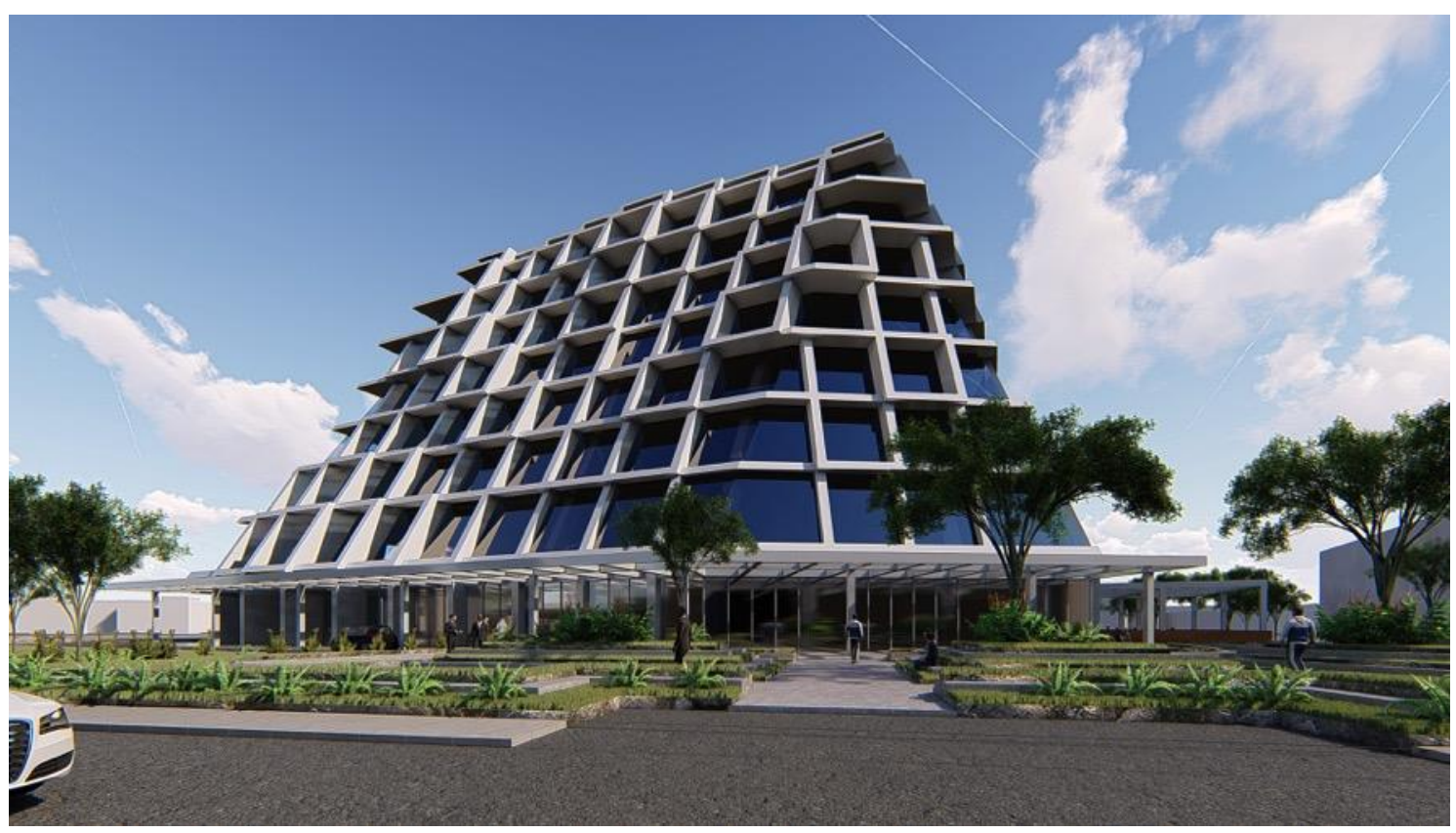

Gambar 8. Perspektif Eksterior Utama Sumber: Penulis, 2019

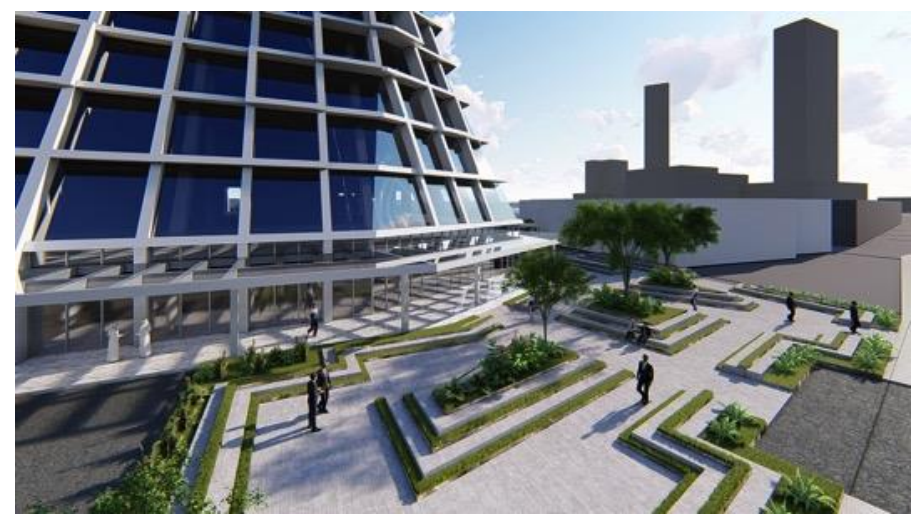

Gambar 9. Perspektif Eksterior Pedestrian Entrance Sumber: Penulis, 2019

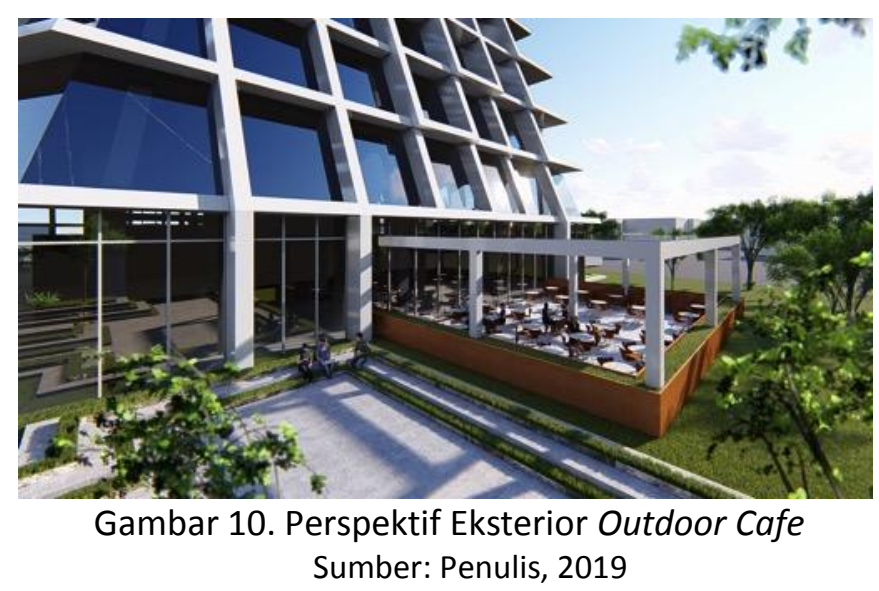




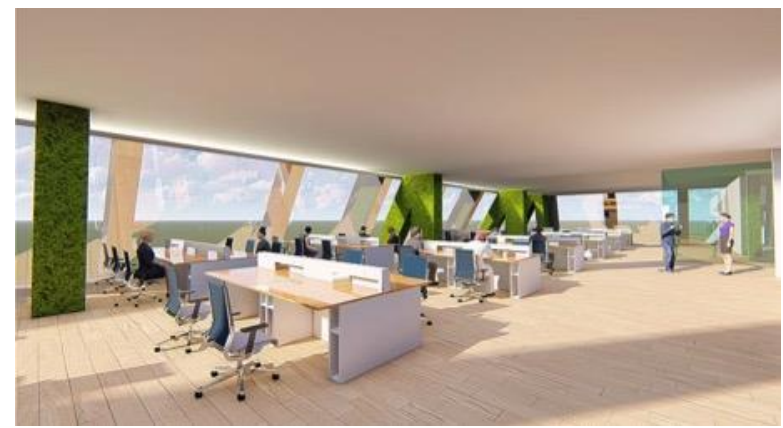

Gambar 11. Perspektif Interior Co-Working Area Sumber: Penulis, 2019

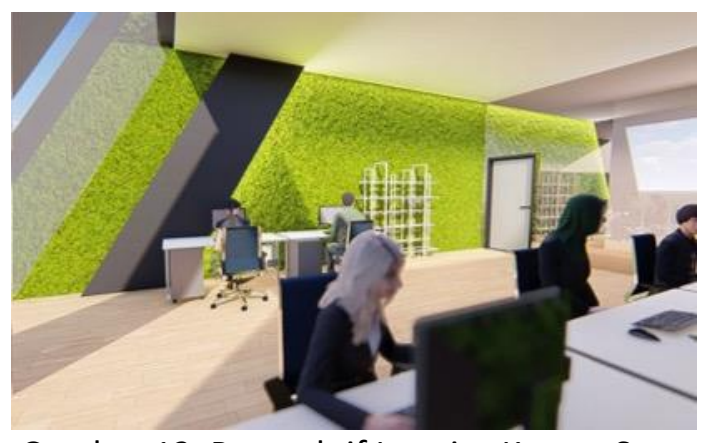

Gambar 12. Perspektif Interior Kantor Sewa Sumber: Penulis, 2019

\section{Aktivitas Program}

\section{a. Kantor Sewa}

Tempat kerja terbagi menjadi ruangan - ruangan layaknya private office dengan tampak depan dari kaca sehingga freelancer dapat mendisplay / memamerkan hasil karya mereka. Selain itu, private office ini dapat menjadi tempat penyimpanan alat - alat pribadi yang mensupport mereka dalam menciptakan suatu desain. Private office ini juga dapat menjadi tempat dimana freelancer dapat mencari inspirasi dengan menyendiri dan jauh dari kebisingan aktivitas creative hub.

\section{b. Workshop}

Pada tempat ini, para freelancer dapat menghasilkan produk dengan menggunakan hard skill mereka. Disetiap workshop terdapat meja - meja dimana mereka bisa berkolaborasi dan berdiskusi mengenai desain yang mereka buat maupun cara mengoperasikan alat tersebut dengan sesama freelancer dan operatornya. Pembatas ruangan menggunakan kaca untuk memberikan kesan yang luas, selain itu juga dapat memotivasi pengunjung yang berkunjung agar dapat mengembangkan usahanya disini. Terdapat 3 ruang workshop yang dibagi atas dasar material yang dipakai:

- 3D Printing and Laser Cutting Room

Pada workshop ini, freelancer dapat membuat karya desain 3D dengan menggunakan material plastik yang diproduksi oleh mesin CNC 3D Printing dan Laser Cutting yang didesain secara virtual melalui komputer. Dalam pengoperasiannya digunakan komputer operator sehingga hasil desain yang ingin dibuat harus melalui komputer tersebut.

- $\quad$ Fashion Room

Workshop ini adalah tempat bagi freelancer yang menekuni bidang desain fashion untuk membuat karya fashion. Pada ruangan ini terdapat alat - alat yang akan membantu proses pembuatan desain fashion, seperti mesin jahit, mesin potong, dan manekin. 
- $\quad$ CNC Machine Room

Workshop ini terdapat CNC Milling Machine yang dapat memotong dan memahat kayu. Proses desain dilakukan secara virtual di dalam komputer dan proses pembentukan fisiknya dilakukan oleh mesin. Dalam pengoperasiannya digunakan komputer operator sehingga hasil desain yang ingin dibuat harus melalui komputer tersebut.

c. Exhibition

Terdapat exhibition untuk memamerkan produk karya desain 3D, fashion, dan instalasi yang dibuat oleh freelancer yang bekerja di creative hub. Dengan berkembangnya teknologi, informasi terhadap produk desain ditampilkan secara interactive dalam layar digital. Ruangan yang luas tidak akan membuat suasana terlalu kosong, melainkan karya yang pamerkan dapat membentuk cerita dan ruang tertentu. Exhibition ini bertujuan untuk mendatangkan masyarakat atau konsumen dari skala lokal, regional, dan internasional untuk melihat - lihat dan membeli hasil karya freelancer. Disamping itu juga, freelancer juga dapat menambah network dan memperluas bidang usaha mereka.

d. Ruang Kelas

Ditempat ini akan diselenggarakan berbagai kegiatan, seperti talk show, seminar, dan workshop. Freelancer Creative Hub dan masyarakat dalam skala lokal, regional, dan internasional dapat mengikuti event yang diselenggarakan. Event yang diselenggarakan dapat melatih hard skill, yaitu penguasaan dalam menggunakan program dan soft skill, yaitu adanya lecture tentang ide, gagasan, dan konsep.

e. Meeting Room

Meeting room sebagai fasilitas bagi freelancer dapat bertemu dan mempresentasikan profil maupun porfolio mereka secara pribadi kepada klien. Bentuk presentasi yang dapat digunakan dalam meeting room adalah tatap muka dan interaksi langsung maupun melalui video call. Dengan 2 cara ini, meeting menjadi lebih fleksibel dan tidak ada alasan berhalangan sehingga pengembangan usaha menjadi lebih lancar.

f. Ruang Baca dan Material Sample

Ruang baca menjadi ruang yang digunakan paran penggunan maupun pengunjung creative hub untuk meningkatkan kemampuan dan ide mereka, sedangkan ruang material sample menjadi area yang dapat untuk mengeksporasi material sehingga dapat menghasilkan suatu karya yang bervariasi.

g. Kantor Pengelola

Kantor managemen dirancang tidak terlalu formal dengan suasana yang nyaman. Terdapat front desk dengan ruang tamu dan ruangan kantor dan ruang meeting cukup disekat oleh kaca. Kegiatan yang dilakukan adalah sebagai pengelola dan mengurus administrasi freelancer yang menggunakan fasilitas dan mengembangkan usaha di creative hub.

h. Café

Café dapat menjadi area kolaboratif dan tempat mencari inspirasi. Dapat juga menjadi area meeting alternative dengan klien dengan suasana yang lebih informal.

\section{KESIMPULAN DAN SARAN}

\section{Kesimpulan}

Lokasi tapak yang berada di Kebon Jeruk memberikan efek positif bagi generasi milenial yang ingin terjun ke industri kreatif karena sejalan dengan kebijakan Pemda Kota Administrasi Jakarta Barat sebagai Service City, kebijakan sektor industri pengolahan lebih berorientasi kepada pengembangan industri pilihan (selected industry).

Dengan program yang dibentuk dari metode interaksi dengan mengkoneksikan antar variabel pada matrix yang akan membentuk program ruang yang sesuai dengan karakteristik, kinerja, kemampuan dan teknologi pada generasi milenial tanpa mengesampingkan generasi sebelumnya dan sudah dapat mewadahi dan menfasilitasi generasi milenial yang akan bekerja dibidang industri kreatif. 


\section{Saran}

Meskipun proyek yang diusulkan merupakan creative hub, tetapi belum memenuhi unsur kreatif dalam aspek eksterior dan interior dan lebih mementingkan aspek efisiensi ruang dikarenakan creative hub digunakan untuk kegiatan bisnis sehingga diusahakan meminimalisir ruang tidak terpakai. Maka dari itu, dapat disarankan untuk melakukan studi ruang gerak yang lebih kompleks sehingga dapat membentuk ruang kreatif yang efisien.

\section{REFERENSI}

Abadi, M. (2019). A college professor who taught a course on 'adulting' says millennials don't consider themselves adults until a milestone they're delaying longer than ever. Diambil kembali dari Business Insider: https://www.businessinsider.in/a-college-professor-whotaught-a-course-on-adulting-says-millennials-dont-consider-themselves-adults-until-amilestone-theyre-delaying-longer-than-ever/articleshow/67397194.cms

Agustina, H., Handiyatmo, D., \& Zoraya, E. (2013). Proyeksi Penduduk Indonesia 2010 - 2035. Jakarta: Badan Pusat Statistik.

ALi, H., \& Purwandi, L. (2016). Indonesia 2020: The Urban Middle-Class Millenials. Jakarta: Alvara.

Ayuni, S., Budiati, I., \& Susianto, Y. (2018). Statistik Gender Tematik: Profil Generasi Milenial Indonesia. Jakarta: Kementerian Pemberdayaan Perempuan dan Perlindungan Anak.

Bridgwater, A. (2019). A Software Strategy For Generation Z. Diambil kembali dari Forbes: https://www.forbes.com/sites/adrianbridgwater/2019/02/04/a-software-strategy-forgeneration-z/\#7af5c2ab209e

Dovey, J., \& Pratt, A. C. (2016). Creative Hub: Understanding the New Economy. London: British Council.

Evans, G. (2009). Creative Cities, Creative Spaces and Urban Policy. London: Sage Publication.

Folia, R. (2019). Kondisi Finansial Bikin Millennials Amerika Serikat Malas Punya Anak. Diambil kembali dari IDN Times: https://www.idntimes.com/news/world/rosa-folia/kondisifinansial-bikin-millennials-amerika-serikat-malas-punya-anak

Hariyanti, D. (2018). Bekraf Bidik PDB Ekonomi Kreatif Rp 1.200 Triliun pada 2019. Diambil kembali dari Kata Data: https://katadata.co.id/berita/2018/10/17/tahun-depan-bekrafbidik-pdb-ekonomi-kreatif-rp-1200-triliun

Hartono, I. (2016). Statistik Daerah Kebon Jeruk 2016. Jakarta: Badan Pusat Statistik.

Jones, C. (2018). More Millennials want freelance careers instead of working full-time. Diambil kembali dari USA Today: https://www.usatoday.com/story/money/2018/04/15/millennialsmore-interested-freelance-careers/512851002/

Kurz, C., Li, G., \& Vine, D. J. (2018). Are Millenials Different. Washington: Board of Governors of the Federal Reserve System.

Munir, R. (2017). Pengertian Kantor, Tujuan, Fungsi, Ciri-Ciri, Unsur-Unsur, dan Jenis-Jenis Kantor Modern di Indonesia. Diambil kembali dari Teropong: https://forum.teropong.id/2017/10/13/pengertian-kantor-tujuan-fungsi-ciri-ciri-unsurunsur-dan-jenis-jenis-kantor-modern-di-indonesiaa/

Smith, N. (2019). Burned-Out Millennials Need Careers, Not Just Jobs. Diambil kembali dari Bloomberg: https://www.bloomberg.com/opinion/articles/2019-01-09/millennial-burnoutyoung-adults-need-careers-not-jobs

Sullivan, E. (2018). Why Aren't Millennials Spending? They're Poorer Than Previous Generations, Fed Says. Diambil kembali dari NPR: https://www.npr.org/2018/11/30/672103209/why-arent-millennials-spending-more-theyre-poorer-than-their-parents-fed-says

Taylor, P., \& Jeeter, S. (2010). Millenials: Confident, Connected, and Open to Change. Washington: PewResearch. 
Virani, T. E. (2014). Re-articulating the creative hub concept as a model for business support in the local creative economy. London: Creativeworks London.

Vomiero, J. (2018). Millennials born in 1980s may never recover from the Great Recession.

Diambil kembali dari Global News: https://globalnews.ca/news/4227642/millennials-1980sgreat-recession/ 